Tér és Társadalom 16. évf. 2002/4. 137-142. p.

Tér és Társadalom

XVI. évf. 2002

4: $137-156$

\title{
KÖNYVJELZÖ
}

\section{SZIRMAI VIKTÓRIA - A. GERGELY ANDRÁS - BARÁTH GABRIELLA - MOLNÁR BALÁZS - SZÉPVÖLGYI ÁKOS: VERSENY ÉS/VAGY EGYÜTTMÜKÖDÉS? Város és környéke kapcsolatai}

(MTA Szociológiai Kutatóintézet, MTA RKK NYUTI Középdunántúli Kutatócsoport, Budapest-Székesfehérvár, 2002, 233 o.)

\section{NAGY ERIKA}

A gazdaság és a társadalom nyolcvanas években zajló strukturális átalakulását modellező társadalomtudományi elméletek egyik alapvető kérdésköre az értelmes és cselekvőképes egyén szerepe, helye e folyamatokban. A probléma - gyakorlati, kutatás-módszertani okokból - sem volt elválasztható az egyén számára cselekvési lehetöséget biztosító társadalmi kapcsolatrendszer fizikai körülményeitől, a földrajzi tértöl (Thrift 1983; Giddens 1984). Az elméletekre épülő empirikus vizsgálatok egyik legfontosabb akadályát azonban éppen a cselekvés szinterének lehatárolása jelenti. Ebben a vonatkozásban a legelterjedtebb, és a globalizáció folyamatával összefüggésben gyakran használt - bár sokat vitatott - kategória a lokalitás, amelyet többnyire társadalmi kapcsolatọk dinamikus, konkrét fizikai határokkal nem rendelkezö rendszereként definiálnak. A lokális kapcsolatrendszerek jelentik az egyén számára a cselekvés elsődleges kereteit a fennálló struktúrák átalakítására, ugyanakkor tükrözik azokat a folyamatokat, amelyek létrehozták (és újratermelik) azokat (Sayer 1984; Cooke 1989; Massey 1991). A kilencvenes évek közepétöl kezdve a lokális gazdasági, társadalmi jelenségek makroszintü, illetve nemzetközi folyamatokba és kapcsolatrendszerekbe ágyazottsága került a kutatások középpontjába, nem utolsó sorban az intézményi és gazdasági globalizáció kiteljesedése és az arra adott lokális válaszok gyarapodása miatt (Smith 1993; Glassman 2001).

Erre a problémakörre koncentrálnak a Verseny és/vagy együttmúködés c. könyv szerzöi is, akik a településhatárokon túllépve, intenzív gazdasági és társadalmi kapcsolatokra épülő térségekben - a Tatabánya-Tata-Oroszlány városegyüttes térségében, illetve Miskolcon és környékén - vizsgálták a rendszerváltozás és a globalizáció következményeit, az átalakulás eredményeként jelentkező strukturális válságra adott válaszokat és azok térbeli-társadalmi, illetve környezeti hatásait. A kutatás hipotézise szerint a városok hosszú távú, fenntartható fejlődése csak a gazdasági, a társadalmi és környezeti érdekek, illetve az azokat megjelenítő stratégiák egyensúlyára épülhet, s ez az egyensúly nem képzelhetỏ el a város és vidékének 
„egyenrangú partneri viszonyon nyugvó kooperációja” (39. o.) nélkül. Ezért az európai városhálózatba, illetve a globális gazdaságba való integráció - a kilencvenes évek végéig jellemzö felfogástól eltérően - csak akkor lehet a települési siker alapja, ha az átalakulással járó helyi és térségi konfliktusokat feltárják, és a szereplök megpróbálják azokat közösen megoldani. Ennek megfelelöen a szerzők több térbeli dimenzióban (szinten) vizsgálták az átmenet időszakának folyamatait, a helyi (elsősorban városi) gazdaság és társadalom átalakulása mellett a város-város kapcsolatokra, város és vidéke viszonyának alakulására, illetve a településközi kapcsolatok regionális sajátosságaira is kitértek. Mindezt az átmenet egész időszakára, több mint egy évtizedre visszatekintve tették. Ez lehetôvé tette a válságkezelés és a globális gazdaságba való beágyazódás folyamatainak szakaszolását, és az egyes települések, illetve térségek jelenlegi állapotának (gazdasági és társadalmi struktúrájának), illetve környezetükkel fennálló kapcsolataik minöségének megfeleltetését e szakaszoknak. A könyv nem csupán a siker eddiginél jóval tágabb értelmezése miatt, hanem a vizsgálati terepek - az új városok - sajátosságai elemzése révén is hozzájárul a fenntarthatóság, illetve a lokalitás/globalizáció tárgykörében zajló elméleti vitákhoz, elsősorban e települések függöségi rendszerei átalakulásának, illetve az erre irányuló stratégiák feltárásával.

A sikeresség és fenntartható növekedés sajâtos megközelítéséböl adódóan a kutatók módszertani bázisa olyan elemeket foglalt magában, amelyek lehetővé tették a helyi/térségi érdekek és a helyi gazdaság és társadalom különböző szereplöi stratégiáinak feltárását. A sajtóanyagok, település- és térségfejlesztési dokumentumok, illetve a mélyinterjúk ezt a célt szolgálták. A rendelkezésre álló információkat a kutatás hipotézisében, illetve kutatási célokban (39-41. o.) megfogalmazott szempontok szerint rendszerezték és dolgozták fel a szerzök. A könyv fóbb fejezeteiben tehát a gazdasági válság strukturális sajátosságait és kezelését, ez utóbbi folyamat tényezőit, a gazdasági átalakulás térbeli/térségi aspektusait, a társadalmi kapcsolatrendszereket és térbeli konfliktusokat, a környezeti problémákat, valamint a civil társadalmi szerveződések szerepét állítják középpontba a szerzők.

A fejezetek közül a leghangsúlyosabb, illetve legnagyobb terjedelmủ a gazdasági kapcsolatrendszerekkel foglalkozó rész, amely a válságból történó kilăbalás, a szerkezetváltás folyamatát tekinti át, elemezve az egyes szereplók elvárásait, stratégiáit. A szocialista nagyipar vălsága, teljes iparágak eltủnése mindkét vizsgált térségben a munkanélküliség növekedését, a szolgáltatások színvonalának hanyatlását, a háztartások szintjén pedig növekvő bizonytalanságot, a hátrányos helyzet halmozódását eredményezte. A kutatók szerint ebben a helyzetben, a szocialista ipar egykori fellegváraiban két gazdaságfejlesztési stratégia hatásai mutathatók ki: az állami segítségre, szerepvállalásra (részben az újvárosi hagyományokra) épülö, illetve a helyi gazdaság szerkezeti és szervezeti átalakítását külső, elsősorban globális szereplők bevonásával megvalósító fejlesztési elképzelések. Ez utóbbi stratégia megvalósítása lehetővé tette a korábbi (állami, jparszerkezeti) függőségi rendszerekböl történö kilépést, amit valamennyi, a gazdasági átalakulásban érdekelt szereplő fontosnak tartott és támogatott. 
E törekvés sikeres példájának Tatabánya tekinthetö (amely részben megmagyarázza, miért Komárom-Esztergom megye volt a hazai ipar egyik legdinamikusabban növekvő térsége az utóbbi öt évben), a szerzők nyilvánvalóan ezért elemzik ezt a modellt a legrészletesebben. Következtetéseik szerint a helyi iparban lejátszódott gyors szerkezeti átalakulásban (diverzifikálódásban) meghatározó szerepet játszott a külföldi múködötőke, melynek letelepedését - a város már létező „tőkéi”, a kedvező földrajzi-közlekedési helyzet, az ipari hagyományok és a szabad munkaerö mellett - a helyi vezetők stratégiája, illetve ennek következetes megvalósitása (ipari területek biztosítása infrastruktúra-fejlesztéssel, részben rekultivációval, az intézményi szolgáltatások színvonalának javítása, operatív fejlesztő szervezet müködtetése, a környezeti károk kezelése, a negatív imázs átalakítása) ösztönözte. Tatabánya gazdasági bázisa átalakulásának áttekintése több szempontból is tanulságos (a szerzők nem véletlenül tárgyalják a vizsgált települések közül a legnagyobb terjedelemben ezt a példát). Áttekinthetjük egy olyan modell müködését, amelyet a térség (és valószínüleg az ország más ipari települései is) számára követendönek, vonzónak tartanak, ugyanakkor a különböző szereplök véleménye felszínre hozta az átalakulás helyi ellentmondásait (a helyi kis- és középvállalkozások, illetve a multik kapcsolatrendszerének gyengeségét, a kevésbé képzett csoportok növekvő súlyát a munkaerő-piaci struktúrában, a hazai kvalifikált munkaerő nem kellő megbecsülését, a gazdasági szerkezet sérülékenységét a beszállítói tevékenységek magas aránya miatt stb.), amelyek tanulságosak lehetnek hasonló stratégiát építő települések, térségek számára.

A gazdasági átalakulásból következő térségi (településközi) feszültségek, konfliktusok tárgyalása, azok típusainak elkülönítése a tatabányai, illetve a miskolci térségben - e sorok írója szerint - a könyv egyik legérdekesebb része. A „követô”" pozícióban levő, ipari válsággal küzdő Oroszlány, és az elmúlt évtizedben leszakadó, sajátos adottságokkal rendelkező Tata (idegenforgalmi potenciál, polgári hagyományok, megosztott helyi társadalom és vezetés) szerepének, illetve a megyeszékhelyhez füződö viszonyának tárgyalása, illetve a két megyeszékhelyet övezö községek átalakulása és sajátos stratégiáik (nyitottság-bezárkózás, önállósodás-a kapcsolatok szorosabbra füzése) elemzése során magyarázatot kapunk egy sor olyan jelenségre (pl. a városok körüli településgyürủ differenciálódására), amelyek pusztán az adatok áttekintésével nem értelmezhetök. A könyv egyik fontos következtetése a településközi/térségi kapcsolatrendszerek sajátosságainak, intenzitásának összefüggése a városi gazdaság dinamizmusával, globális gazdaságba történő integrációjảval, illetve e folyamatok társadalmi-térbeli következményeivel. A szerzök szerint a nyitottság, a közös problémák és érdekek felismerése, a térségi kapcsolatok erősítése elengedhetetlen a városi (térségi) gazdaság fenntartható növekedéséhez egy olyan függési (elosztási) rendszerben, amelyben a globális szereplök és az állami intézmények a meghatározó szereplők, és hiányoznak a társadalmi (térségi) összefogás hagyományai, mechanizmusai

A társadalmi kapcsolatrendszerek átalakulását a szerzök - nyilvánvalóan a folyamat új vonásai és meghatározó jellege miatt - a szuburbanizáció jelenségén 
keresztül tárgyalják. A szerzök tapasztalatai, vizsgálatai szerint a gazdasági válság, illetve Tatabányán az azt kővető kilábalás a társadalmi differenciálódás és a térbeli elkülönülés irányába hatott alapvetően, amely a városok belső tereit, illetve a környező településeket is érintették, átalakítva, átértelmezve a korábbi térbelitársadalmi kapcsolatrendszereket. Az alacsonyabb státuszcsoportok kisebb, olcsóbb lakásba, illetve a környező falvakba történő költözése mellett az elmúlt évtizedben a magasabb státuszcsoportok „kifelé” irányuló mozgása is meghatározó folyamat volt. E jelenségeket a gazdasági átalakulás (közvetve a globalizáció) térbelitársadalmi következményeinek tekintik a szerzők, azonban fontos taszító tényezőként említik a kibocsátó településeken az („örökölt”) lakókörnyezet romló minőségét is. A szuburbanizációs folyamatok társadalmi-gazdasági feszültségeket keltettek a befogadó településeken, a kibocsátó centrumokban - még a dinamikusan fejlödő Tatabányán is - pedig felvetették a fenntarthatóság (pl. demográfiai egyensúly, slumosodás) kérdését, érdekeltté téve az érintett településeket a problémák közös kezelésében, az együttmüködésben.

A fenti problémákkal szorosan összefüggö kérdéseket vet fel a térbeli társadalmi konfliktusokat tárgyaló, harmadik fejezet. A kutatók szerint az átalakulás során termelődő (esetleg újratermelỏdő) társadalmi konfliktusok ,... akadályozzák a gazdaság dinamizálódását, ... a térségi együttmükỏdés, az autonómia kialakulását, ... végsỏ soron pedig a helyi társadalom mentális értelemben vett sikerességét, jó közérzetét, településhez való kötődésének minőségét." (133.0.) Az egyik alapvetö kérdés ebben az összefüggésben a vizsgált városok, térségek társadalmának viszonyulása a globalizációhoz, illetve annak szereplöihez. A konfliktusok egyik forrása a nemzetközi szereplök érintőleges integrációja a helyi gazdaságba és társadalomba, ezzel összefüggésben a hazai és külföldi szakmai elit konfliktusait, illetve a helyi vállalkozások valós vagy vélt hátrányait emelték ki a szerzők. Az átalakulási és az ezzel párhuzamosan zajló globalizációs (integrációs) folyamat legföbb kritikusait a civil szervezetek körében találták meg a kutatók. Ezek képviselői az elszegényedés, a szegregáció, a lakáspiaci feszuiltségek mellett a lakókörnyezet minőségét is bírálták.

A Tatabánya-Oroszlány-Tata térségében végzett kutatás vélhetően egyik legfontosabb következtetése, hogy a gazdasági válság enyhülése után felbomlik a helyi társadalmi csoportok között a válság enyhítésére létrejött konszenzus, és sor kerül a társadalmi (köztük környezettel, egészségủggyel, oktatással összefüggő) konfliktusok meg fogalmazására, erösödik az igény ezek kezelésére. A kutatók szerint a felzárkózó, gazdaságilag dinamikus városokban ennek ellenére a városfejlesztési stratégiákban, a tervezési dokumentumokban továbbra is a gazdaságfejlesztési szempontok a meghatározóak, s a társadalmi, környezeti és egyéb érdekek, problémák ennek alárendelten jelennek meg (ezt tükrözi pl. az alapos, átfogó társadalmi és környezeti hatásvizsgálatok hiánya). Nem véletlen, hogy az ezzel kapcsolatos kritikákat és a városfejlesztéssel kapcsolatos új elvárásaikat (amelyek tükrözik a helyi társadalom különbözö csoportjai, illetve a gazdasági szereplök és az önkormányzat közötti konfliktusokat) elsősorban a tatabányai civil szervezetek fogalmazták meg. 
A szerzök részletesen elemzik a (gazdasági, politikai és civil szférára tagolódó) elit csoportok konfliktusait, valamint a társadalmi státuszcsoportok közötti feszültségeket is, amelyek eltérỏ módon jelentek meg az átalakulás és a globalizációs hatások különbözö fázisaiban (Tatabánya/Oroszlány), a különbözỏ társadalmi, kulturális hagyományokkal rendelkezö településeken (Tatabánya/Tata), s nem függetlenek ,a térségi szerepkörök kínálta profiloktól” (165. o.) sem. A társadalmi konfliktusok vizsgálata során a szerzők túlléptek a településhatárokon, és a városok közötti, illetve a város-városkörnyék kapcsolatrendszer ellentmondásait is feltárták. Egészében véve a telepuilésközi együttmúködésre való hajlandóság észrevehetö erősödését regisztrálták, ám a centrumszerepre törekvés, az ezzel összefüggő városok közötti - viszályok még akadályozzák a térségi együttmüködést, a (valódi) partneri viszony kialakulását. A kutatás eredményei szerint a sikeres gazdasági szerkezetváltás - a globális gazdaságban betöltött kedvezőbb helyzet - újratermelte a centrumfunkciókat, megteremtette a város és (akár tágabb) környéke szerves integrációjának feltételeit (Tatabánya esetében), s lehetővé tette az újonnan felmerülö konfliktusok közös kezelését (szemben pl, a miskolci térséggel). A fejezet fontos üzenete, hogy egy-egy térség településeit ellenmondásokkal teli kapcsolatok kötik össze, amelyek - bár vannak közös jellemzőik - nem írhatók le általános sémákkal. A települések konfliktusai a helyi társadalmakban, a településhierarchiában elfoglalt helyükben, politikai kapcsolatrendszerükben, a globális gazdaságba való beágyazottságukban gyökereznek, feltárásuk tehát csak a tatabányai és miskolci térségek ben végzett vizsgálatokhoz hasonló „,mélyfúrásokkal” lehetséges.

A globalizáció hatásaival kapcsolatos viták egyik sarkalatos kérdése a szegényebb országok környezeti értelemben vett kizsákmányolása. A törvényi háttér hiányosságai és a civil szféra gyengesége miatt a Magyarországon - és különösen a könyvben vizsgált ipari térségekben - élök egészségét tehát örökölt és új keletü környezeti ártalmak is veszélyeztetik. A negyedik fejezet e problémára koncentráló elemzése szerint az ipari térségek lakossága ellentmondásosan viszonyul az ilyen jellegü problémákhoz. Környezeti érzékenységük ugyan növekedett, de „... a környezeti érdekek érvényesítésére vonatkozó posztmateriális értékek a munkahely biztonságával együtt jelennek meg", vagyis az itt élők hajlandóak a kompromisszumra környezetük rovására is a gazdasági stabilitás megőrzése érdekében. Bár a vizsgálatok szerint az elmúlt néhány évben a civil társadalomhoz közel álló csoportok igyekeztek megjeleníteni a környezeti érdekeket, ez utóbbiak érvényesülése részben a gazdasági elit ellenérdekeltsége és a helyi stratégiák kialakításában betöltött kulcsszerepe, részben a környezeti érdekek széles körü felismerésének hiánya, illetve az azokat képviselỏ civil szervezetek csekély társadalmi támogatottsága és politikaipénzügyi függése miatt kevéssé volt jellemző.

A környezeti érdekek megjelenítése, képviselete és érvényesítése korlátjainak, fogyatékosságainak feltárása felszínre hozta azokat az alapvető sajátosságokat, amelyek az átalakuló helyi társadalmakra, azok müködésére jellemzőek. A sajátos vonások közé sorolhatjuk a civil szervezetek helyi társadalomban betöltött szerepét, amelyet a szerzők az ötödik fejezetben részletesen tárgyalnak. Következtetéseik szerint a szervezetek gyenge társadalmi beágyazottsága és támogatottsága, erős 
pénzügyi függése (a központi és helyi kormányzattól), megosztottságuk, az általuk megfogalmazott és képviselt alternatív stratégiák hiánya oda vezetett, hogy a város(illetve térség-) fejlesztés irányainak kialakításakor mellőzik őket, legalábbis csekély súlya van az általuk megfogalmazott véleményeknek. Ez a szerzök következtetései szerint a helyi és térségi tervezés társadalmi bázisának növelése ellen hat, a helyi társadalom kiszolgáltatott néhány (elsősorban gazdasági) érdekcsoportnak, és mindez a fejlödés fenntarthatóságát veszélyezteti. Városonként jelentős eltéréseket találtak a kutatók a civil szféra súlyában és szerepében - e tekintetben az újvárosi „hagyományok", illetve a polgárosult Tata eltérö modellt testesítenek meg -, de a kutatás eredményei szerint a társadalmi szervezetek megosztottsága (Tatán pl. a válságra adott sikertelen válaszok miatt) is lehet a fejlödés (kilábalás) akadálya.

Egy új szakkönyvet olvasva mindenkiben felmerül a kérdés, hogy kiknek is szólnak, illetve milyen módon hasznosíthatók az abban leírt eredmények, következtetések. Ha - Nyugat-Európához, Észak-Amerikához hasonlóan - a hazai tudományos életben is „,bevett” és elfogadott kategória lenne a különbözö diszciplínákat összefogó, integráló „,várostudomány” (urban studies) a verseny és/vagy együttmüködés kérdését körüljáró kutatás eredményeit elsösorban nekik ajánlhatnánk jó szívvel. A szerzők ugyanis oly módon adnak átfogó képet két térség - elsősorban azok városi centrumai - gazdasági-társadalmi átalakulási folyamatairól és globális gazdaságba történő illeszkedéséröl, hogy felhasználják a szociológia, a közgazdaságtan, a geográfia, a regionális és környezettudomány (helyenként a történettudomány) elméleti hátterét, kategóriáit és módszertani eszköztárát. A hazai városkutatások müvelőinek szól tehát e könyv elsősorban, s azért is, mert a jelenlegi „felhalmozási szakaszban” végzett „mélyfúrások” során kristályosodnak ki azok a vonások, amelyek a keletközép-európai helyi társadalmak sajátos viszonyulását jellemzik a globalizáció folyamatához (annak jelenségeihez), s amelyek e régió múltjában/közelmúltjában gyökereznek. Ily módon a globalizáció, a lokalitás, a fenntarthatóság és a várostervezés témakörében zajló (nemzetközi), illetve az azokkal összefüggő elméleti vitákhoz is hozzájárul a könyv empirikus vizsgálatokon alapuló következtetéseivel. Ugyanakkor fontos, a település- és térségi tervezésben hasznosítható tanulságokkal is bőségesen szolgál e könyv mindazok számára, akik részt vesznek a stratégiaalkotásban és a tervek megvalósításában, illetve e folyamatok előkészítésében.

\section{Irodalom}

Cooke, P. (1989) Locality, Economic Restrucluring and World Development. - Cooke, P. (ed.) Localities: the changing face of urban britain. Unwin Hamyn, London. 1-41. o.

Glassman, (2001) From Seattle (and Ubon) to Bangkok: the scales of resistance to corporate globalization. - Environment and Planning D: Society and Space. vol. 19. 513-533. o.

Giddens, A. (1984) The constitution of society. Polity Press, Cambridge. 3-55. o.

Massey, D. (1991) The political place of of locality studies. - Environment and Planning A. 23. 267-281. o.

Sayer, (1984) Method in social science: a realist approach. Hutchinson, London.

Smith, (1993) Homeless/global scaling places in Mapping the the Futures, - Bird, J.-Curtis, B.-Putnam, T.Robertson, G.-Tickner, L. (eds.) Local Cultures, Global Change. Routledge, London. 87-119. o.

Thrift, N. (1983) On the determination of social action in space and time. - Environment and Planning D: Society and Space. vol. 1, 23-57. o. 